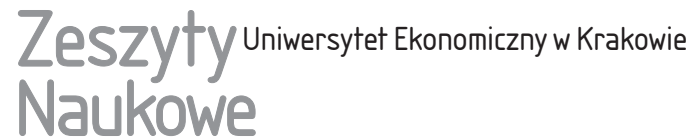

\section{Mechanical Properties of Lining Leathers Finished with the Addition of Oregano Essential Oil}

\begin{abstract}
The hygienic properties of lining leathers can be improved significantly by introducing oregano essential oil into leathers. This is because adding antiseptic oil makes leathers more resistant to microorganisms that are potentially harmful to humans and cause damage to animal leathers. The paper presents the results of tests to check selected mechanical properties - tensile strength, elongation and tear load - of leathers fatliquored with oregano essential oil at a concentration of $3 \% \mathrm{w} / \mathrm{w}$ and without this treatment. The tests were carried out on the Instron 5544 testing machine.

The leathers enriched with oil met the standard requirements set for lining leathers for of the parameters: tensile strength and elongation. Statistical analysis using the chi-squared, Hartley and Fisher-Snedecor tests at an assumed significance level of $\alpha=0.05$ revealed that leather enriched with oregano essential oil has a significantly higher tensile strength than leather fatliquored without this oil, while both leather samples

Elżbieta Bielak, Cracow University of Economics, Faculty of Commodity Science and Product Management, Department of Industrial Commodity Science, Rakowicka 27, 31-510 Kraków, e-mail: bielake@uek.krakow.pl

Ewa Marcinkowska, Cracow University of Economics, Faculty of Commodity Science and Product Management, Department of Industrial Commodity Science, Rakowicka 27, 31-510 Kraków, e-mail: etmarcin@cyf-kr.edu.pl

* This paper presents the results of a research project co-financed from Ministry of Science and Higher Education funds granted to the Faculty of Commodity Science at the Cracow University of Economics for research projects implemented by young scientists and doctoral research fellows and for maintaining research potential.
\end{abstract}


showed no significant difference in elongation and tear load. Thus, it can be concluded that adding $3 \% \mathrm{w} / \mathrm{w}$ of oil will have not have an adverse effect on basic mechanical properties of leathers.

Keywords: lining leathers, oregano oil, tensile strength, elongation, tear load. JEL Classification: L67.

\section{Introduction}

Leather is a valuable raw material for manufacturing goods used by humans in different areas of life. After stripping the hide from the body of an animal, it is delivered to a tannery and subjected to various treatments and operations to get the features customers seek. Depending on its intended use, the leather is given specific properties. Garment leathers should be very soft and flexible, while gloving leathers should have appropriate extensibility and sweat resistance, and sole leathers must be wear-resistant and have low absorbability (Duda \& Marcinkowska 2001).

An important feature of lining leathers are their hygienic properties, given their close and often prolonged contact with the user's body. These properties of materials, used for sock linings, linings and uppers determine, are what lend the materials their comfort of use. They include, first and foremost, water vapour permeability and sweat absorbability (Skrzyńska et al. 2006). The hygienic properties of shoes are also connected with providing appropriate microbiological purity, thus also ensuring the health and safety of users. The studies conducted by E. Bielak (2016) and E. Bielak et al. (2016) confirmed that fatliquoring leathers with oregano oil with antiseptic action allows leather to take on antimicrobial properties, thus it can improve the hygienic properties of shoes, the insides of which are made of enriched leather.

Product standards provide requirements to be met by leathers for specific intended uses. Requirements related to mechanical strength are among the most basic. Mechanical properties of leathers are influenced by many factors, including type of leather, tanning and finishing methods, water and fat content. The actual location on the piece of leather from which the sample is taken is also important, because in the topographical layout of the leather there are large differences in tensile strength and extensibility (Raabe \& Kornaś 1965).

The aim of this paper is to present research targeted at determining the possible effect which oregano oil (3\%) introduced into leather during the finishing phase has on the basic mechanical properties of cowhide lining leather, i.e. tensile strength, elongation and tear load. Tests were performed according to methodology specified in PN-EN ISO 3376:2012 Leather - Physical and mechanical tests - Determination of tensile strength and percentage extension and PN-EN 
ISO 3377-1:2012 Leather - Physical and mechanical tests - Determination of tear load - Part 1: Single edge tear. The results were subjected to statistical analysis by using the chi-squared, Hartley and Fisher-Snedecor tests.

\section{Materials and Methods}

\subsection{Lining Leather Enriched with Oregano Oil}

The tests were carried out on cowhide leather designed for shoe lining, which was chrome tanned and shaved to a thickness of 1.4 to $1.6 \mathrm{~mm}$ in a tannery. "Wet-blue”, the semi-processed product, was purchased from PPHU „Techno-Skór”, bath finished with and without the addition of Portuguese essential oil derived from Origanum vulgare plants. The oil was obtained from the Industrial and Experimental Laboratory at the PWSZ Krosno.

\section{Leather Bath Finishing}

Original samples (rectangles, $150 \times 250 \mathrm{~mm}( \pm 10 \mathrm{~mm})$ were taken from "wet-blue" butt according to the schematic presented in Figure 1, weighed and placed in triples in Wacker-type drums for bath finishing.

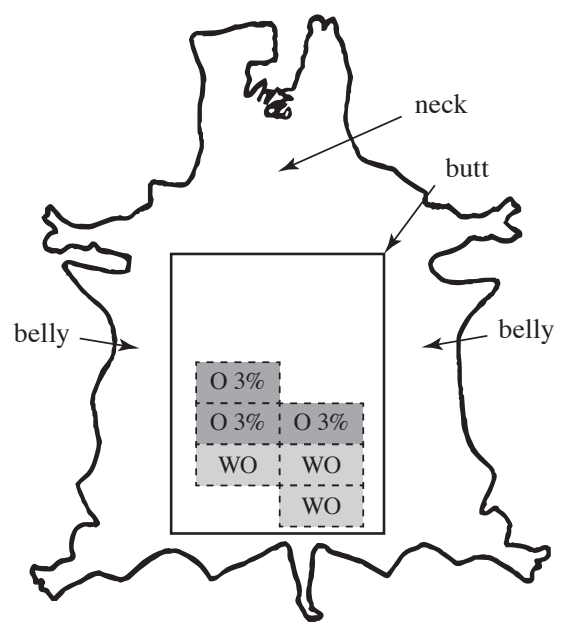

O $3 \%$ - samples to be fatliquored with the addition of $3 \%$ oregano oil WO - samples to be fatliquored without addition of the oil

Fig. 1. Origin of the Samples

Source: authors' own research, cowhide leather, shape based on (Mięso-podstawy... 2011). 
The following operations were performed in sequence: soaking, retanning I, rinsing, retanning II, fixation and rinsing. During retanning II, oregano oil at a concentration of 3\% (w/w) (Bielak 2016) was added to give the leather antimicrobial properties. After the 8-hour finishing cycle the original samples were hung to dry for one day, and then kept in a horizontal position for 10 days to remove excess moisture. Afterwards, the material was placed in paper envelopes and stored at room temperature. The control samples were leathers fatliquored according to the indicated procedure without the essential oil and emulsifying agent.

\section{Preparing Laboratory Specimens}

The original samples subjected to bath finishing were cut into laboratory specimens by using a hand press and steel punching dies of shape and size specified in applicable standards.

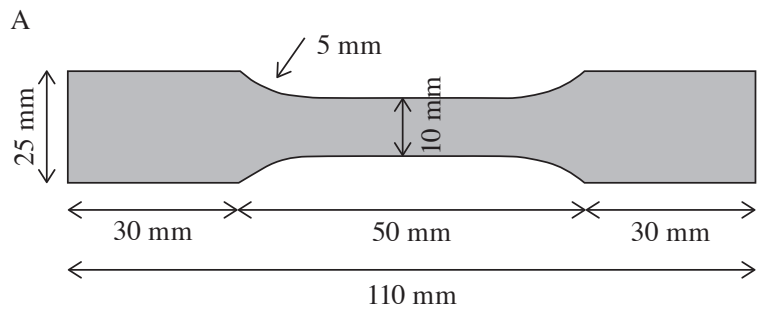

B

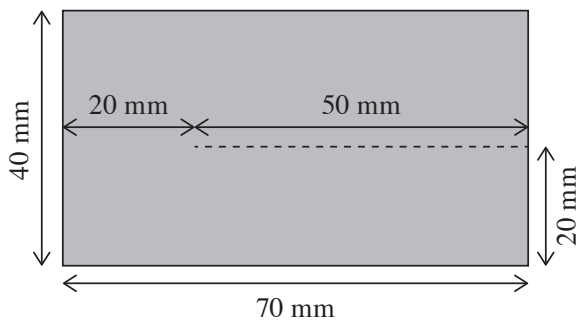

Fig. 2. Shapes and Sizes of Tensile Strength and Percentage Elongation Test Specimens (A), Tear Load, Single-edge Tear Test Pieces (B) Source: authors' own research based on (PN-EN ISO 3376:2012, PN-EN ISO 3377-1:2012).

The specimens for tensile strength and percentage elongation testing (Figure 2A) were prepared according to PN-EN ISO 3376:2012. As lining leathers belong to soft leathers, the specimen width was $10 \mathrm{~mm}$, complying with the standard. For each kind of leather (fatliquored with or without the addition of oregano oil), nine speci- 
mens were cut parallel and perpendicular to the backbone. This number was thrice larger than that recommended by the standard (PN-EN ISO 3376:2012), which enabled statistical analysis to improve the accuracy and reliability of the obtained results. Thickness was measured with a thickness gauge according to PN-EN ISO 2589:2016-05 Leather - Physical and mechanical tests - Determination of thickness.

To measure tear load, rectangular test pieces with an incision were prepared (Figure 2B), according to the schematic presented in PN-EN ISO 3377-1:2012. For each kind of leather (fatliquored with or without the addition of oregano oil), three specimens were cut parallel and perpendicular to the backbone (PN-EN ISO 3377-1:2012). Thickness was measured with a thickness gauge (PN-EN ISO 2589:2016-05).

Before testing, the samples (Figure 2) were conditioned at $20 \pm 2^{\circ} \mathrm{C}$ and $65 \pm 5 \%$ RH for 48 hours according to PN-EN ISO 2419:2012 Leather - Physical and mechanical tests - Sample preparation and conditioning.

\subsection{Mechanical Properties Test Methods}

The tests were carried out at the strength testing laboratory at the Faculty of Commodity Science and Product Management, Cracow University of Economics, with an Instron 5544 universal tester equipped with a measuring head of force capacity of up to $1000 \mathrm{~N}$. Samples of leather (Figure 2) fatliquored with and without oregano oil at a concentration of $3 \%$ per leather weight were tested.

\section{Tensile Strength and Percentage Elongation}

Tensile strength and percentage elongation tests were carried out according to guidelines outlined in PN-EN ISO 3376:2012. The method consists in stretching a leather specimen at a speed of $100 \pm 20 \mathrm{~mm} / \mathrm{min}$ until it eventually breaks (the instrument is stopped when tensile force drops by $20 \%$ within $100 \mathrm{~ms}$ ). Tensile force acting on the sample at break as well as gauge section elongation were measured and recorded.

The samples (Figure 2A) were clamped in the instrument's jaws, separated by a distance of $50 \pm 1 \mathrm{~mm}$. Once started, the tester was allowed to run until the sample broke. Based on the results, the tensile strength in MPa and percentage elongation of gauge section were calculated.

\section{Tear Load (Single Edge Tear)}

Tear load (single edge tear) was tested according to PN-EN ISO 3377-1:2012. The method consists in stretching a rectangular test piece on the shorter side so that tear begins from the end of an incision. The tear load is then recorded. 
The gripping jaws of the Instron 5544 tester were set $50 \pm 1 \mathrm{~mm}$ from each other. In the lower jaw, a 20-mm section of one specimen tongue (Figure 2B) was gripped, while the other one, after being bent to $180^{\circ}$, was clamped in the upper jaw. Once started, the testing machine was run until the test piece was completely torn. Based on the recorded measurements, tear load in $\mathrm{N}$ was determined.

\subsection{Methods of Statistical Analysis}

For statistical analysis with the Statistica 12 software package (Dobosz 2001, Mynarski 2003), the results of tensile strength and elongation tests as well as tear load tests carried out on the leather fatliquored with and without the addition of oregano oil (3\%) were used. In the first stage, the values of basic statistical measures were calculated: arithmetic mean $(\bar{x})$ and standard deviation $\left(s_{d}\right)$, and then, in the second stage, variance analysis was carried out. Initially, two hypotheses in variance analysis were verified:

- the empirical distributions comply with a hypothetical (normal) distribution, which was verified by chi-squared test,

- the variance was homogenic, a fact verified by Harley's test.

After confirming these hypotheses, a substantive hypothesis on differentiation of the selected indices depending on the addition of oregano essential oil at concentration of 3\% per leather weight was verified with a one-way analysis of variance and Fisher-Snedecor test. Statistical inference was drawn at a significance level of $\alpha=0.05$.

\section{Results and Discussion}

The results of tensile strength and percentage elongation tests for specimens of leather fatliquored without and with the addition of oregano oil at a concentration of $3 \%$ per leather weight are presented in Tables 1 and 2. For each specimen, the values of thickness, breaking force, tensile strength and percentage elongation are given. The parameters' arithmetic means and standard deviations were computed for specimens cut both parallel and perpendicular to the backbone.

The test specimens of leather fatliquored without and with the addition of oregano oil at concentration of $3 \%$ per leather weight and cut along the backbone were characterized by higher tensile strength (13.7 MPa and 16.6 MPa, respectively) than those cut crosswise (10.8 $\mathrm{MPa}$ and $11.8 \mathrm{MPa}$, correspondingly) (Table 1-2), a fact consistent with the literature (Raabe and Kornaś 1965).

An inverse relationship was recorded for percentage elongation. The specimens of leather fatliquored without the addition of oregano oil and cut along the back- 
bone had a percentage elongation of $53 \%$, while for those cut crosswise the figure reached $67 \%$ (Table 1). For specimens of leather fatliquored with the addition of $(3 \%)$ oregano oil, the percentage elongation of specimens taken parallel and perpendicular to the backbone was $50 \%$ and $66 \%$ respectively (Table 2). The thickness of the samples fatliquored without and with the addition of oregano oil was comparable. The average thickness of specimens ranged between $1.63-1.66 \mathrm{~mm}$ (Table 1-2).

Table 1. Tensile Strength and Percentage Elongation for the Leather Fatliquored without the Addition of Oregano Oil

\begin{tabular}{|c|c|c|c|c|}
\hline $\begin{array}{c}\text { Specimen no } \\
\text { and its orientation } \\
\text { to the backbone }\end{array}$ & $\begin{array}{c}\text { Thickness, } \\
\text { mm }\end{array}$ & $\begin{array}{c}\text { Breaking force, } \\
\text { N }\end{array}$ & $\begin{array}{c}\text { Tensile strength, } \\
\text { MPa }\end{array}$ & $\begin{array}{c}\text { Elongation, } \\
\%\end{array}$ \\
\hline \multicolumn{5}{|c|}{ Parallel } \\
\hline 1 & 1.83 & 254.72 & 13.92 & 55.00 \\
\hline 2 & 1.67 & 252.65 & 15.13 & 57.34 \\
\hline 3 & 1.54 & 208.45 & 13.54 & 58.00 \\
\hline 4 & 1.56 & 212.02 & 13.59 & 52.00 \\
\hline 5 & 1.61 & 216.08 & 13.42 & 47.34 \\
\hline 6 & 1.67 & 221.80 & 13.28 & 51.66 \\
\hline 7 & 1.65 & 219.82 & 13.32 & 55.66 \\
\hline 8 & 1.65 & 219.20 & 13.28 & 53.34 \\
\hline 9 & 1.59 & 215.48 & 13.55 & 53.34 \\
\hline $\bar{x}$ & 1.64 & 224 & 13.7 & 53 \\
\hline$s_{d}$ & 0.09 & 17 & 0.6 & 3.3 \\
\hline \multicolumn{5}{|c|}{ Perpendicular } \\
\hline 1 & 1.53 & 157.38 & 10.29 & 64.66 \\
\hline 2 & 1.57 & 169.96 & 10.83 & 65.00 \\
\hline 3 & 1.56 & 162.14 & 10.39 & 64.66 \\
\hline 4 & 1.59 & 171.38 & 10.78 & 61.00 \\
\hline 5 & 1.63 & 172.18 & 10.56 & 76.34 \\
\hline 6 & 1.67 & 178.85 & 10.71 & 71.66 \\
\hline 7 & 1.79 & 210.04 & 11.73 & 66.66 \\
\hline 8 & 1.74 & 195.02 & 11.21 & 68.66 \\
\hline 9 & 1.72 & 179.83 & 10.46 & 69.34 \\
\hline $\bar{x}$ & 1.64 & 177 & 10.8 & 67 \\
\hline$s_{d}$ & 0.09 & 16 & 0.5 & 4.6 \\
\hline
\end{tabular}

Source: authors' own research. 
Table 2. Tensile Strength and Percentage Elongation for the Leather Fatliquored with the Addition of Oregano Oil

\begin{tabular}{|c|c|c|c|c|}
\hline $\begin{array}{l}\text { Specimen no } \\
\text { and its orientation } \\
\text { to the backbone }\end{array}$ & $\begin{array}{l}\text { Thickness, } \\
\text { mm }\end{array}$ & $\begin{array}{c}\text { Breaking force, } \\
\mathrm{N}\end{array}$ & $\begin{array}{l}\text { Tensile strength, } \\
\mathrm{MPa}\end{array}$ & $\begin{array}{c}\text { Elongation, } \\
\%\end{array}$ \\
\hline \multicolumn{5}{|c|}{ Parallel } \\
\hline 1 & 1.77 & 325.54 & 18.39 & 52.00 \\
\hline 2 & 1.69 & 277.77 & 16.44 & 50.34 \\
\hline 3 & 1.60 & 235.41 & 14.71 & 52.34 \\
\hline 4 & 1.65 & 271.01 & 16.42 & 50.66 \\
\hline 5 & 1.61 & 250.99 & 15.59 & 46.34 \\
\hline 6 & 1.63 & 270.16 & 16.57 & 56.00 \\
\hline 7 & 1.71 & 289.46 & 16.93 & 45.66 \\
\hline 8 & 1.61 & 262.41 & 16.30 & 41.00 \\
\hline 9 & 1.71 & 307.59 & 17.99 & 52.34 \\
\hline $\bar{x}$ & 1.66 & 276 & 16.6 & 50 \\
\hline$s_{d}$ & 0.06 & 27.7 & 1.1 & 4.5 \\
\hline \multicolumn{5}{|c|}{ Perpendicular } \\
\hline 1 & 1.69 & 224.73 & 13.30 & 72.00 \\
\hline 2 & 1.67 & 224.39 & 13.44 & 62.34 \\
\hline 3 & 1.56 & 158.54 & 10.16 & 60.00 \\
\hline 4 & 1.59 & 174.26 & 10.96 & 63.00 \\
\hline 5 & 1.67 & 186.83 & 11.19 & 71.34 \\
\hline 6 & 1.57 & 170.63 & 10.87 & 63.34 \\
\hline 7 & 1.56 & 168.54 & 10.80 & 66.00 \\
\hline 8 & 1.62 & 174.83 & 10.79 & 66.66 \\
\hline 9 & 1.75 & 252.68 & 14.44 & 69.34 \\
\hline $\bar{x}$ & 1.63 & 192 & 11.8 & 66 \\
\hline$s_{d}$ & 0.07 & 32.7 & 1.5 & 4.2 \\
\hline
\end{tabular}

Source: authors' own research.

The values of the mean and standard deviation of tensile strength and percentage elongation for individual kinds of leather are listed in Table 3. Leather enriched with oregano oil had a higher tensile strength (14.2 MPa) than leather without the addition of oil (12.2 MPa) (Table 3). With regard to the tensile strength tests, the leathers met the requirements for lining leathers specified in PN-P-22218:1986 Light leather - Lining leathers (tensile strength for lining leathers - whole cowhide leather, half-hide leather, back, and butts or necks should not be less than $9 \mathrm{MPa}$ ). 
The larger value of the percentage elongation parameter was recorded for leather without oregano oil (61\%). The leathers with the oil added were characterised by $58 \%$ elongation (Table 3). For lining leathers, the percentage elongation should not be less than 30\% (PN-P-22218:1986). The results indicate that the leathers under investigation met this requirement.

Table 3. Comparison of Tensile Strength and Percentage Elongation for Individual Leathers

\begin{tabular}{|l|c|c|c|c|}
\hline \multirow{2}{*}{\multicolumn{2}{|c|}{ Leather }} & \multicolumn{2}{|c|}{ Tensile strength } & \multicolumn{2}{c|}{ Elongation } \\
\cline { 2 - 5 } & $\bar{x}, \mathrm{MPa}$ & $s_{d}$ & $\bar{x}, \%$ & $s_{d}$ \\
\hline Fatliquored without oregano oil & 12.2 & 1.6 & 61 & 8.1 \\
\hline Fatliquored with oregano oil (3\%) & 14.2 & 2.8 & 58 & 9.4 \\
\hline
\end{tabular}

Source: authors' own research.

The tensile strength and percentage elongation tests carried out on lining leathers without and with the addition of oregano oil at concentration of $3 \%$ per leather weight showed that leather enriched with this natural substance meets requirements for these two parameters for lining leathers.

The results of tear load (single edge tear) tests for specimens of leather fatliquored without and with the addition of oregano oil at a concentration of $3 \%$ per leather weight are presented in Table 4-5. For each sample, the values of thickness and tear load are given. The arithmetic means and standard deviations for these parameters were computed both for specimens cut parallel and perpendicular to the backbone.

For leathers fatliquored without and with the addition of oregano oil (3\%), higher tear loads were recorded for test pieces cut parallel to the backbone (40 N and $44 \mathrm{~N}$, correspondingly) than for samples cut crosswise (34 N and $27 \mathrm{~N}$, accordingly). The thickness of the samples fatliquored without and with the addition of oregano oil was comparable. The average thickness of specimens ranged between $1.58-1.68 \mathrm{~mm}$ (Table 4-5).

The mean values of tear load along with standard deviations for leathers fatliquored without and with the oregano oil (3\%) are listed in Table 6. The values obtained for tear load for individual kinds of leather were very close. For leather fatliquored without oregano oil, a slightly higher tear load $(37 \mathrm{~N})$ was recorded than for leather fatliquored with the addition of a natural substance $(36 \mathrm{~N})$. 
Table 4. Tear Load for the Leather Fatliquored without the Addition of Oregano Oil

\begin{tabular}{|c|c|c|c|c|}
\hline \multirow{2}{*}{$\begin{array}{c}\text { Specimen no } \\
\text { and its orientation } \\
\text { to the backbone }\end{array}$} & $\begin{array}{c}\text { Thickness, } \\
\mathrm{mm}\end{array}$ & $\begin{array}{c}\text { Tear load, } \\
\mathrm{N}\end{array}$ & $\begin{array}{c}\text { Thickness, } \\
\mathrm{mm}\end{array}$ & $\begin{array}{c}\text { Tear load, } \\
\mathrm{N}\end{array}$ \\
\cline { 2 - 5 } & \multicolumn{2}{|c|}{ parallel } & \multicolumn{2}{c|}{ perpendicular } \\
\hline 1 & 1.85 & 41.88 & 1.63 & 38.02 \\
\hline 2 & 1.56 & 38.37 & 1.54 & 28.77 \\
\hline 3 & 1.62 & 39.29 & 1.60 & 34.53 \\
\hline $\bar{x}$ & 1.68 & 40 & 1.59 & 34 \\
\hline$s_{d}$ & 0.15 & 1.8 & 0.05 & 4.7 \\
\hline
\end{tabular}

Source: authors' own research.

Table 5. Tear Load for the Leather Fatliquored with the Addition of Oregano Oil (3\%)

\begin{tabular}{|c|c|c|c|c|}
\hline \multirow{2}{*}{$\begin{array}{c}\text { Specimen no } \\
\text { and its orientation } \\
\text { to the backbone }\end{array}$} & $\begin{array}{c}\text { Thickness, } \\
\mathrm{mm}\end{array}$ & $\begin{array}{c}\text { Tear load, } \\
\mathrm{N}\end{array}$ & $\begin{array}{c}\text { Thickness, } \\
\mathrm{mm}\end{array}$ & $\begin{array}{c}\text { Tear load, } \\
\mathrm{N}\end{array}$ \\
\cline { 2 - 5 } & \multicolumn{2}{|c|}{ parallel } & \multicolumn{2}{c|}{ perpendicular } \\
\hline 1 & 1.67 & 43.37 & 1.60 & 27.53 \\
\hline 2 & 1.69 & 57.06 & 1.61 & 31.36 \\
\hline 3 & 1.58 & 30.15 & 1.53 & 23.56 \\
\hline $\bar{x}$ & 1.65 & 44 & 1.58 & 27 \\
\hline$s_{d}$ & 0.06 & 13.5 & 0.04 & 3.9 \\
\hline
\end{tabular}

Source: authors' own research.

Table 6. Comparison of Tear Load for Individual Kinds of Leather

\begin{tabular}{|l|c|c|}
\hline \multirow{2}{*}{\multicolumn{1}{|c|}{ Leather }} & \multicolumn{2}{|c|}{ Tear load } \\
\cline { 2 - 3 } & $\bar{x}, \mathrm{~N}$ & $s_{d}$ \\
\hline Fatliquored without oregano oil & 37 & 4.6 \\
\hline Fatliquored with oregano oil (3\%) & 36 & 12.5 \\
\hline
\end{tabular}

Source: authors' own research.

The results of tensile strength, percentage elongation and tear load for individual kinds of leather were subjected to statistical analysis. Table 7 presents the results of the analysis confirming that the empirical distributions are compatible with the normal distribution, tested by chi-square compliance test. The values of $\chi^{2}$ indicated that all empirical distributions under investigation are close to normal distribution ( $p>\alpha$, where $\alpha=0.05)$. 
Table 7. The Results of Tests on Normal Distribution of Test Results

\begin{tabular}{|l|c|c|c|c|c|c|}
\hline \multirow{2}{*}{ Leather } & \multicolumn{2}{|c|}{ Tensile strength } & \multicolumn{2}{c|}{ Elongation } & \multicolumn{2}{c|}{ Tear load } \\
\cline { 2 - 7 } & $\chi^{2}$ & $p$ & $\chi^{2}$ & $p$ & $\chi^{2}$ & $p$ \\
\hline Fatliquored without oregano oil & 11.25 & 0.277 & 3.59 & 0.999 & 1.67 & 0.989 \\
\hline Fatliquored with oregano oil (3\%) & 10.52 & 0.310 & 3.87 & 0.998 & 7.49 & 0.824 \\
\hline
\end{tabular}

Source: authors' own research.

The results on the homogeneity of variation checked by means of Hartley $F_{\max }$ test are shown in Table 8 . The hypothesis on the homogeneity of variation was not rejected, because the values of $F_{\max }$ were less than the limit value $F_{\text {max }}(\alpha=0.05)=5.39$.

Table 8. Results of Testing for Homogeneity of Variation

\begin{tabular}{|l|c|c|c|}
\hline \multirow{2}{*}{\multicolumn{1}{|c|}{ Leather }} & Tensile strength & Elongation & Tear load \\
\cline { 2 - 4 } & \multicolumn{3}{|c|}{$s_{d}^{2}$} \\
\hline Fatliquored without oregano oil & 2.48 & 65.23 & 21.12 \\
\hline Fatliquored with oregano oil (3\%) & 7.83 & 88.89 & 75.72 \\
\hline Calculated values of $F_{\text {max }}$ & 3.15 & 1.36 & 3.58 \\
\hline Limit value $F_{\max }$ & \multicolumn{3}{|c|}{$F_{\max }(\alpha=0.05)=5.93$} \\
\hline
\end{tabular}

Source: authors' own research.

Table 9. Differentiation of Tensile Strength, Percentage Elongation and Tear Load by Leather Type - Results of Analysis of Variance

\begin{tabular}{|l|c|c|c|}
\hline \multirow{2}{*}{ Leather } & $\begin{array}{c}\text { Tensile strength, } \\
\mathrm{MPa}\end{array}$ & $\begin{array}{c}\text { Elongation, } \\
\%\end{array}$ & $\begin{array}{c}\text { Tear load, } \\
\mathrm{N}\end{array}$ \\
\cline { 2 - 4 } & \multicolumn{3}{|c|}{} \\
\hline Fatliquored without oregano oil & 12.22 & 60.65 & 36.81 \\
\hline Fatliquored with oregano oil (3\%) & 14.18 & 57.82 & 35.51 \\
\hline \multicolumn{4}{|c|}{ Analysis of variance } \\
\hline$F$ & 6.71 & 0.94 & 0.05 \\
\hline$p$ & 0.014 & 0.340 & 0.815 \\
\hline
\end{tabular}

Source: authors' own research.

Afterwards, the hypothesis on differentiation of the levels of selected parameters depending on the kind of leather (fatliquored without and with the addition of oregano oil) was verified with one-way analysis of variance using the 
Fisher-Snedecor $F$ test. The results of analysis are presented in Table 9. The values of test probability $p$ indicated a significant differentiation of tensile strength by type of leather $(p<0.05)$ and that both percentage elongation and tear load do not depend on the leather type used $(p>0.05)$.

\section{Conclusions}

In the light of the research, the following conclusions to be drawn:

1. Lining leather enriched with oregano oil (3\%) meets the requirements for lining leathers specified in the product standard regarding tensile strength and percentage elongation.

2. Tensile strength for leather fatliquored with the addition of oregano oil (3\%) is significantly higher than that of leather fatliquored without the addition of oregano oil.

3. Percentage elongation for leather fatliquored with the addition of oregano oil (3\%) does not differ significantly from that obtained for leather fatliquored without the addition of oregano oil.

4. Tear load for leather fatliquored with the addition of oregano oil (3\%) does not differ significantly from that obtained for leather fatliquored without it.

5. Introducing the oil derived from Origanum vulgare into the leather bath finishing process improves the tensile strength of leather, while the addition of this oil has no effect, neither advantageous nor adverse, on percentage elongation and tear load.

\section{Bibliography}

Bielak E. (2016), Wpływ wykończenia olejkami eterycznymi skór podszewkowych na ich właściwości higieniczne, praca doktorska, Uniwersytet Ekonomiczny w Krakowie, Kraków.

Bielak E., Marcinkowska E., Syguła-Cholewińska J., Golonka J. (2016), An Examination of Antimicrobial Activity of Lining Leathers Fatliquored with Essential Oils, "The Journal of the American Leather Chemists Association", vol. 111, no 6.

Dobosz M. (2001), Wspomagana komputerowo statystyczna analiza wyników badań, Akademicka Oficyna Wydawnicza EXIT, Warszawa.

Duda I., Marcinkowska E. (2001), Towaroznawstwo wyrobów skórzanych i futrzarskich, Wydawnictwo Akademii Ekonomicznej w Krakowie, Kraków.

Mięso - podstawy nauki i technologii (2011), eds A. Pisula, E. Pospiech, Wydawnictwo Szkoły Głównej Gospodarstwa Wiejskiego, Warszawa.

Mynarski S. (2003), Analiza danych rynkowych i marketingowych z wykorzystaniem programu Statistica, Wydawnictwo Akademii Ekonomicznej w Krakowie, Kraków. 
PN-EN ISO 2419:2012 Leather - Physical and mechanical tests - Sample preparation and conditioning.

PN-EN ISO 2589:2016-05 Leather - Physical and mechanical tests - Determination of thickness.

PN-EN ISO 3376:2012 Leather - Physical and mechanical tests - Determination of tensile strength and percentage extension.

PN-EN ISO 3377-1:2012 Leather - Physical and mechanical tests - Determination of tear load - Part 1: Single edge tear.

PN-P-22218:1986 Light leather - Lining leathers.

Raabe E., Kornaś A. (1965), Właściwości fizyczne skór. Metody badań, Wydawnictwo Przemysłu Lekkiego i Spożywczego, Warszawa.

Skrzyńska B., Kmiecik-Serafin S., Wyczesana J., Rajchel-Chyla B., Gajewski R. (2006), ABC sprzedawcy obuwia, czyli co każdy sprzedawca o obuwiu wiedzieć powinien, CLPO, Kraków.

\section{Właściwości mechaniczne skór podszewkowych wykończonych z dodatkiem olejku lebiodkowego}

(Streszczenie)

Higieniczność skór podszewkowych można znacząco poprawić dzięki wprowadzeniu do skóry olejku lebiodkowego, ponieważ dodatek olejku o działaniu antyseptycznym pozwala na nadanie skórze oporności wobec mikroorganizmów potencjalnie szkodliwych dla człowieka oraz powodujących destrukcję skór zwierzęcych. W artykule przedstawiono wyniki badań wybranych właściwości mechanicznych skór natłuszczonych z dodatkiem oraz bez dodatku olejku lebiodkowego w stężeniu 3\% na masę skóry, tj. wytrzymałości na rozciąganie, wydłużenia i siły rozdzierającej, które wykonano na maszynie wytrzymałościowej Instron 5544.

Skóry uszlachetnione olejkiem spełniały wymagania podane w normie wyrobu stawiane skórom podszewkowym w zakresie wytrzymałości na rozciąganie oraz wydłużenia. Analiza statystyczna z wykorzystaniem testów chi-kwadrat, Hartleya oraz Fishera-Snedecora przy przyjętym poziomie istotności $\alpha=0,05$ wykazała, że w przypadku badanych próbek wytrzymałość na rozciąganie skóry z dodatkiem olejku lebiodkowego była istotnie wyższa od wartości tego parametru w skórze natłuszczonej bez dodatku olejku, zaś wydłużenie oraz siła rozdzierająca skóry z dodatkiem olejku nie różniły się istotnie od wydłużenia i siły rozdzierającej skóry bez dodatku substancji naturalnej. Można zatem stwierdzić, że dodatek olejku w ilości 3\% na masę skóry nie będzie miał niekorzystnego wpływu na podstawowe właściwości mechaniczne skór uszlachetnionych tym olejkiem.

Słowa kluczowe: skóry podszewkowe, olejek lebiodkowy, wytrzymałość na rozciąganie, wydłużenie, siła rozdzierająca. 